\title{
Implementasi Pendekatan Saintifik Pada Sintaks Discovery/Inquiry Learning, Based Learning, Project Based Learning
}

\author{
Asmin Banawi ${ }^{1}$ \\ ${ }^{1}$ Widyaiswara LPMP Maluku \\ ${ }^{1}$ Email: asbanawi@gmail.com
}

\begin{abstract}
Abstrak: Salah satu tuntutan kurikulum 2013 adalah penggunaan pendekatan saintifik dalam pembelajaran. Adanya pendekatan tersebut tentunya memerlukan pengetahuan memadai oleh guru tentang pembelajaran dan implementasinya di kelas. Oleh karena itu, tujuan dalam kajian ini adalah menguraikan hubungan lima tahapan pendekatan saintifik (5M) dengan sintaks beberapa model pembelajaran (discovery/inquiry learning, based learning, project based learning). Untuk menjawab tujuan tersebut digunakan referensi dan hasil penelitian yang relevan melalui studi kepustakaan. Analisis hubungan lima tahapan pendekatan saintifik dengan sintaks model pembelajaran dilakukan dengan pendekatan struktural. Hasil kajian menunjukkan bahwa pendekatan saintifik dapat digunakan secara bersama-sama dengan model pembelajaran. Lima tahapan pendekatan saintifik dapat disenergikan dengan sintaks model pembelajaran yang ada. Hasil kajian ini merupakan bekal pengetahuan bagi guru dalam menyusun rencana pembelajaran dan menerapkannya dalam pembelajaran di kelas.
\end{abstract}

\section{Kata Kunci: Pendekatan Saintifik, Sintaks, Doscovery Learning}

Abstract: One of the demands of the 2013 curriculum is the use of a scientific approach to learning. The existence of this approach certainly requires adequate knowledge by the teacher about learning and its implementation in the classroom. Therefore, the purpose of this study is to describe the relationship of the five stages of the scientific approach $(5 \mathrm{M})$ with the syntax of several learning models (discovery/inquiry learning, based learning, project based learning). To answer these objectives, references and relevant research results are used through library studies. Analysis of the relationship of the five stages of the scientific approach to the syntax of the learning model is done by a structural approach. The results of the study indicate that the scientific approach can be used together with the learning model. The five stages of the scientific approach can be synchronized with the syntax of the existing learning model. The results of this study are the provision of knowledge for teachers in preparing learning plans and applying them in classroom learning.

Key Words: Scientific Approach, Syntax, Doscovery Learning

Undang-Undang Nomor 20 Tahun 2003 tentang Sistem Pendidikan Nasional, menjelaskan bahwa kegiatan pembelajaran adalah proses interaksi peserta didik dengan 
pendidik dan sumber belajar pada suatu lingkungan belajar yang bertujuan untuk mengembangkan potensi peserta didik sehingga menjadi manusia yang beriman dan bertakwa kepada Tuhan Yang Maha Esa, berakhlak mulia, sehat, berilmu, cakap, kreatif, mandiri, dan menjadi warga negara yang demokratis serta bertanggung jawab. Berdasarkan tujuan pendidikan, nampak bahwa pembelajaran peserta didik tidak hanya sekedar mengajarkan ilmu saja. Undang-undang tersebut telah meletakkan dasar-dasar yang kuat dalam menopang pembangunan karakter dan jati diri bangsa.

Untuk meningkatkan profesionalisme, seorang guru diharapkan mampu menciptakan dan menerapkan suatu model pembelajaran yang inovatif, sehingga dalam Kegiatan Belajar Mengajar (KBM) akan terjadi pembelajaran multi arah atau adanya interaksi antara guru, siswa dan lingkungan sekitar. Dalam rangka peningkatan kualitas belajar tersebut, pemerintah selalu melakukan perbaikan pada setiap kurikulum yang diterapkan, dan untuk saat ini kurikulum 2013 menjadi pertimbangan bagi pemerintah, dimana kurikulum 2013 merupakan pembaharuan dari kurikulum sebelumnya. Kegiatan pembelajaran dalam kurikulum 2013 diarahkan untuk memberdayakan semua potensi yang dimiliki peserta didik agar merekadapat memiliki kompetensi yang diharapkan melalui upaya menumbuhkan serta mengembangkan sikap (attitude), pengetahuan (knowledge), dan keterampilan (skill).

Dalam kurikulum 2013 pendekatan yang diterapkan adalah pendekatan saintifik (scientific approach) atau pendekatan berbasis keilmuan, dimana dalam kegiatan inti pembelajaran dengan menggunakan pendekatan ini peserta didik diharapkan mampu melaksanakan 5 (lima) tahapan kegiatan. Lima kegiatan inti dalam pembelajaran dengan pendekatan saintifik adalah kegiatan mengamati, menanya, megumpulkan informasi, menalar, dan mengkomunikasikan. Pendekatan saintifik dilaksanakan dengan modus pembelajaran langsung dan tidak langsung. Dalam kurikulum 2013 sebagai penerapan dari pendekatan saintifik, maka dibentuklah model pembelajaran yang dapat dipilih oleh guru yang nantinya akan disesuaikan dengan materi pelajaran. Model pembelajaran dalam kurikulum ini merupakan kerangka konseptual dan operasional pembelajaran yang memiliki nama, ciri, urutan, logis, pengaturan dan budaya. Model pembelajaran dalam kurikulum 2013 antara lain discovery learning, project-based learning, problem-based learning dan inquiry learning (Permendikbud No.103/2014).

Model pembelajaran memiliki urgensi tinggi dalam pengorganisasian proses pembelajaran di dalam kelas secara aktif. Pembelajaran aktif menjadi strategi yang paling popular dalam dunia pembelajaran kekinian. Asumsi yang digunakan dalam pembelajaran aktif adalah siswa menjadi subjek belajar, sedangkan guru diposisikan sebagai pendamping, pengarah atau fasilitator. Hampir semua praktisi pendidikan percaya bahwa pembelajaran aktif akan menghasilkan output sekaligus peserta didik yang kreatif dan mampu menjawab persoalan-persoalan yang dihadapinya di dunia nyata. 
Selain itu, masa depan peserta didik menjadi tidak perlu ditakutkan lagi dikarenakan mereka sudah mampu mengelola secara aktif potensi mereka masing-masing.

Model pembelajaran merupakan pola yang digunakan sebagai pedoman dalam merencanakan pembelajaran di kelas maupun tutorial. Model pembelajaran dapat didefinisikan sebagai kerangka konseptual yang melukiskan prosedur sistematis dalam mengorganisasikan pengalaman belajar untuk mencapai tujuan belajar. Untuk dapat menerapkan model pembelajaran sesuai dengan tuntutan perubahan kurikulum, guru perlu pengetahuan memadai tentang pendekatan dan model pembelajaran yang sesuai dengan kurikulum yang digunakan.

Namun demikian, masih adanya kesulitan guru dalam mensinergikan lima tahapan pendekatan saintifik dengan sintaks dari model pembelajaran yang ada. Untuk itu, kajian hubungan lima tahapan pendekatan saintifik (5M) dengan sintaks beberapa model pembelajaran (discovery/inquiry learning, based learning, project based learning) tersebut masih penting untuk dilakukan. Oleh karena itu, tujuan dalam kajian ini adalah menguraikan hubungan lima tahapan pendekatan saintifik (5M) dengan sintaks beberapa model pembelajaran (discovery/inquiry learning, based learning, project based learning). Diharapkan tulisan ini, dapat memperkaya pengetahuan guru maupun calon guru serta menjadi bahan refleksi bagi mereka dalam menggunakan model pembelajaran tersebut di kelas.

\section{METODE PENELITIAN}

Untuk menjawab permasalahan digunakan referensi dan hasil penelitian yang relevan melalui studi kepustakaan (bibliography study). Analisis hubungan lima tahapan pendekatan saintifik dengan sintaks model pembelajaran dilakukan dengan pendekatan struktural. Pendekatan struktural adalah suatu metode atau cara pencarian terhadap suatu fakta yang sasarannya tidak hanya ditujukan kepada salah satu unsur sebagai individu yang berdiri sendiri di luar kesatuannya, melainkan ditujukan pula kepada hubungan antar unsurnya. Struktural merupakan keseluruhan yang bulat, yaitu bagian-bagian yang membentuknya tidak dapat berdiri sendiri di luar struktural itu.

\section{HASIL DAN PEMBAHASAN \\ Pendekatan Saintifik dan Kurikuklum 2013}

Pendekatan saintifik merupakan kerangka ilmiah pembelajaran yang diusung oleh kurikulum 2013. Langkah-langkah pada pendekatan saintifik merupakan bentuk adaptasi dari langkah-langkah ilmiah pada sains. Proses pembelajaran dapat dipadankan dengan suatu proses ilmiah, karenanya kurikulum 2013 mengamatkan esensi pendekatan saintifik dalam pembelajarannya. Pendekatan saintifik diyakini sebagai titian emas perkembangan dan pengembangan sikap, keterampilan, dan pengetahuan peserta didik. Dalam pendekatan atau proses kerja yang memenuhi kriteria ilmiah, para ilmuan lebih 
mengedepankan penalaran induktif (inductive reasoning) dibandingkan dengan penalaran deduktif (deductive reasoning).

Penalaran deduktif melihat fenomena umum untuk kemudian menarik simpulan yang spesifik. Sebaliknya, penalaran induktif memandang fenomena atau situasi spesifik untuk kemudian menarik simpulan secara keseluruhan. Sejatinya, penalaran induktif menempatkan bukti-bukti spesifik ke dalam relasi ide yang lebih luas. Metode ilmiah umumnya menempatkan fenomena unik dengan kajian spesifik dan detail untuk kemudian merumuskan simpulan umum. Metode ilmiah merujuk pada teknik-teknik investigasi atas suatu atau beberapa fenomena atau gejala, memperoleh pengetahuan baru, atau mengoreksi dan memadukan pengetahuan sebelumnya.

Pendekatan pembelajaran menggunakan pendekatan saintifik/pendekatan berbasis proses keilmuan. Pendekatan saintifik/pendekatan berbasis proses keilmuan merupakan pengorganisasian pengalaman belajar dengan urutan logis yang lebihg dikenal dengan istilah $5 \mathrm{M}$ meliputi proses pembelajaran terdiri dari mengamati, menanya, mengumpulkan informasi/mencoba, menalar/mengasosiasi, dan mengkomunikasikan. Urutan logis dapat dikembangkan dan digunakan dalam satu atau lebih pertemuan. Pendekatan saintifik/pendekatan berbasis proses keilmuan dilaksanakan dengan menggunakan modus pembelajaran langsung atau tidak langsung sebagai landasan dalam menerapkan berbagai strategi dan model pembelajaran sesuai dengan Kompetensi Dasar yang ingin dicapai. Kelima kegiatan pokok 5M (mengamati, menanya, mengumpulkan informasi, menalar atau mengasosiasi, mengkomunikasikan) di atas adalah aktivitas minimal, guru dapat mengembangkannya sesuai dengan kebutuhan.

Pada implementasi kurikulum 2013, guru tidak hanya sekedar membiarkan peserta didik memperoleh/mengkonstruk pengetahuan sendiri, namun guru memberi setiap bantuan yang diperlukan oleh peserta didik, seperti: bertindak sebagai fasilitator, mengatur/mengarahkan kegiatan-kegiatan belajar, memberi umpan balik, memberikan penjelasan, memberi konfirmasi, dan lain-lain.

\section{Lima Tahapan Pendekatan Saintifik dalam Pembelajaran}

Beberapa langkah-langkah pembelajaran saintifik menurut Peraturan Pemerintah Pendidikan dan Kebudayaan tentang Pembelajaran pada Pendidikan Dasar dan Pendidikan Menengah (Permendikbud No.103/2014 tentang Pembelajaran pada dikdasmen) adalah sebagai berikut.

Pertama, Mengamati. Mengamati merupakan metode yang mengutamakan kebermaknaan proses pembelajaran. Kegiatan belajar yang dilakukan dalam proses mengamati adalah membaca, melihat (tanpa atau dengan alat), menyimak, menonton, mendengar, merasa, meraba, mencium dan sebagainya dengan menggunakan panca indera, tanpa atau menggunakan alat bantu. Hasilnya berupa skema dari fakta/fenomena. Kompetensi yang dikembangkan adalah melatih kesungguhan, ketelitian. 
Kedua, Menanya. Menanya merupakan kegiatan pembelajaran yang dilakukan dengan cara membuat dan mengajukan pertanyaan tentang informasi yang tidak dipahami dari apa yang diamati atau pertanyaan untuk mendapatkan informasi tambahan tentang apa yang diamati (dimulai dari pertanyaan faktual, konseptual, prosedural sampai ke pertanyaan hipotetik). Hasilnya berupa pertanyaan rasa ingin tahu terhadap terhadap apa yang belum dipahami. Kompetensi yang dikembangkan adalah mengembangkan kreativitas, rasa ingin tahu, kemampuan merumuskan pertanyaan untuk membentuk pikiran kritis yang perlu untuk hidup cerdas dan belajar sepanjang hayat.

Ketiga, Mengumpulkan Informasi/Mencoba. Mengumpulkan informasi atau eksperimen merupakan kegiatan pembelajaran berupa eksperimen, mencoba sesuatu, mendemonstrasikan, meniru gerak, membaca berbagai sumber, mewawancara narasumber. Hasilnya berupa data/informasi. Kompetensi yang dikembangkan dalam proses mengumpulkan informasi atau eksperimen adalah mengembangkan sikap teliti, jujur, sopan, menghargai pendapat orang lain, kemampuan berkomunikasi, menerapkan kemampuan mengumpulkan informasi melalui berbagai cara yang dipelajari, mengembangkan kebiasaan belajar dan belajar sepanjang hayat.

Pendekatan saintifik berkaitan erat dengan metode saintifik. Metode saintifik (ilmiah) pada umumnya melibatkan kegiatan pengamatan atau observasi yang dibutuhkan untuk perumusan hipotesis atau mengumpulkan data. Metode ilmiah pada umumnya dilandasi dengan pemaparan data yang diperioleh melalui pengamatan atau percobaan. Oleh sebab itu, kegiatan percobaan diganti dengan kegiatan memperoleh informasi dari berbagai sumber (Sani, 2015: 50-51).

Keempat, Menalar/Mengasosiasikan. Mengasosiasikan atau mengolah informasi merupakan kegiatan pembelajaran yang berupa pengolahan informasi, menganalisis data, menemukan pola, menyimpulkan. Hasil dari kegiatan ini adalah data/informasi yang telah diolah dan digeneralisasi. Kompetensi yang dikembangkan dalam proses mengasosiasikan atau mengolah informasi adalah mengembangkan sikap jujur, teliti, disiplin, taat aturan, kerja keras, kemampuan menerapkan prosedur dan kemampuan berpikir induktif serta deduktif dalam menyimpulkan.

Kelima, Mengkomunikasikan. Kegiatan ini dapat dilakukan melalui persentasi, pajang karya, kunjung karya, menyajikan laporan secara lisan atau tertulis mulai dari proses, hasil dan kesimpulan. Kompetensi yang dikembangkan dalam tahapan mengkomunikasikan adalah mengembangkan sikap jujur, teliti, toleransi, kemampuan berpikir sistematis, mengungkapkan pendapat dengan singkat dan jelas, mengembangkan kemampuan bahasa yang baik dan benar. Hasil tugas dikerjakan bersama dalam satu kelompok untuk kemudian dipresentasikan atau dilaporkan kepada guru. Kegiatan menyimpulkan merupakan kelanjutan kegiatan mengolah, bisa dilakukan bersama dalam satu kesatuan kelompok dan dikerjakan sendiri setelah mendengarkan hasil kegiatan mengolah informasi. Hasil tugas yang telah dikerjakan secara kolaboratif dapat disajikan 
dalam bentuk laporan tertulis dan dapat dijadikan sebagai salah satu bahan untuk portofolio kelompok atau individu. Pada tahapan ini kendatipun tugas dikerjakan secara berkelompok, tetapi sebaiknya hasil pencatatan dilakukan oleh masing-masing individu. Portofolio yang di masukkan ke dalam file atau map peserta didik terisi dari hasil pekerjaannya sendiri secara individu. Kegiatan akhir diharapkan peserta didik dapat mengkomunikasikan hasil pekerjaan yang telah disusun baik secara bersama dalam kelompok atau secara individu dari hasil kesimpulan yang telah dibuat bersama. Kegiatan mengkomunikasikan dapat diberikan klarifikasi oleh guru agar supaya peserta didik akan mengetahui secara benar apakah jawaban yang telah dikerjakan sudah benar atau ada yang harus diperbaiki. Menurut Sani (2015: 53) tahapan aktivitas belajar yang dilakukan dengan pembelajaran saintifik tidak harus dilakukan mengikuti prosedur yang kaku, namun disesuaikan dengan pengetahuan yang hendak dipelajari.

Permendikbud No. 103/2014 menghendaki pembelajaran saintifik diperkuat dengan model yang disarankan dalam kurikulum 2013 antara lain; pembelajaran berbasis penemuan (discovery based learning), penelitian atau penyelidikan (inquiry based learning), pembelajaran berbasis masalah (problem based learning) dan pembelajaran berbasis proyek (project based learning). Model pembelajaran merupakan bingkai dari penerapan suatu pendekatan, metode, dan teknik pembelajaran.

\section{Hubungan 5M dengan Discovery/Inquiry Learning}

Teknik penemuan adalah terjemahan dari discovery. Diskoveri adalah proses mental dimana siswa mampu mengasimilasikan sesuatu konsep atau prinsip. Yang dimaksud dengan proses mental tersebut antara lain ialah: mengamati, mencerna, mengerti, menggolong-golongkan, membuat dugaan, menjelaskan, mengukur, membuat kesimpulan dan sebagainya (Roestiyah, 2008: 20). Kegiatan belajar mengajar menggunakan metode penemuan (discovery) mirip dengan inkuiri (inquiry). Inkuiri adalah proses menjawab pertanyaan dan menyelesaikan masalah berdasarkan fakta dan pengamatan, sedangkan diskoveri adalah menemukan konsep melalui serangkaian data atau informasi yang diperoleh melalui pengamatan atau percobaan. Jadi, belajar dengan menemukan (discovery) sebenarnya adalah bagian dari proses inkuiri (Sani, 2015: 97).

Dalam Peraturan Menteri Pendidikan dan Kebudayaan Nomor 22 Tahun 2016 tentang Standar Proses Pendidikan Dasar dan Menengah (Permendikbud No. 22/2016 tentang standar proses dikdasmen) dikatakan bahwa pembelajaran inquiry disebut bersama dengan discovery. Penemuan melalui proses berpikir secara sistematis. Pengetahuaan bukan sekedar sekumpulan fakta hasil dari mengingat, akan tetapi hasil dari proses menemukan atau mengkonstruksi. Dengan kata lain, pembelajaran merupakan proses fasilitasi kegiatan penemuan (inquiry) agar peserta didik memperoleh pengetahuan dan keterampilan melalui penemuannya sendiri (discovery). Menurut Sani (2015) inkuiri dapat dijadikan sebagai pendekatan pembelajaran, strategi pembelajaran, atau metode pembelajaran. Pembelajaran diskoveri dapat dipadukan dengan inkuiri dengan 
mengajukan hipotesis tentang sebuah percobaan. Menurut Herdian (2010) metode pembelajaran discovery (penemuan) adalah metode mengajar yang mengatur pengajaran sedemikian rupa sehingga anak memperoleh pengetahuan yang sebelumnya belum diketahuinya itu tidak melalui pemberitahuan, sebagian atau seluruhnya ditemukan sendiri.

Sintaks Pembelajaran Diskoveri/Inkuiri sebagai berikut: (1) dihadapkan dengan permasalahan, (2) pengumpulan data untuk verifikasi, (3) pengumpulan data dalam eksperimen, (4) organisasi, perumusan, dan penjelasan, dan (5) menganalisis proses inkuiri (Sani, 2015: 97). Selanjutnya sintaks tersebut dihubungkan dengan unsur dalam pendekatan saintifik. Hubungan 5M dengan Pembelajaran Diskoveri/Inkuiri tampak pada Tabel 1 berikut.

Tabel 1. Hubungan 5M dengan Sintaks Pembelajaran Diskoveri/Inkuiri

\begin{tabular}{|l|l|l|}
\hline Kegiatan Pokok 5M & \multicolumn{1}{|c|}{ Sintaks } & \multicolumn{1}{c|}{ Deskripsi } \\
\hline Mengamati & Merumuskan & $\begin{array}{l}\text { Memberi stimulus; bacaan, atau mengamati gambar, atau } \\
\text { situasi, sesuai dengan materi pembelajaran/topik/tema. } \\
\text { Menjadi pembelajar sepanjang hayat, ingin tahu. }\end{array}$ \\
\hline Menanya & Merencanakan & $\begin{array}{l}\text { Mengidentifikasi masalah; mengajukan pertanyaan, } \\
\text { menemukan permasalahan menanya, mencari informasi, } \\
\text { dan merumuskan masalah dan merencanakan prosedur } \\
\text { atau langkah-langkah dan pengumpulan dan analisis data, } \\
\text { kerja keras }\end{array}$ \\
\hline $\begin{array}{l}\text { Mengumpulkan } \\
\text { Informasi }\end{array}$ & $\begin{array}{l}\text { Mengumpulkan } \\
\text { dan menganalisis } \\
\text { data }\end{array}$ & $\begin{array}{l}\text { Kegiatan mengumpulkan informasi, fakta, maupun data, } \\
\text { dilanjutkan dengan kegiatan menganalisis data, } \\
\text { mengajukan kemungkinan jawaban. } \\
\text { Melatih ketelitian, akurasi, dan kejujuran, kerja keras. }\end{array}$ \\
\hline Mengasosiasi & Menarik simpulan & $\begin{array}{l}\text { Memverifikasi; mengecek kebenaran atau keabsahan } \\
\text { hasil pengolahan data, mencari sumber yang relevan baik } \\
\text { dari buku atau media, mengasosiasikannya menjadi suatu } \\
\text { kesimpulan. } \\
\text { Cinta kebenaran }\end{array}$ \\
\hline Mengkomunikasikan & $\begin{array}{l}\text { Aplikasi } \\
\text { Tindak lanjut }\end{array}$ & $\begin{array}{l}\text { Menyajikan hasil temuan, merumuskan kesimpulan } \\
\text { berdasarkan data yang diolah, dan mengeksplorasi } \\
\text { pertanyaan-pertanyaan atau permasalahan lanjutan untuk } \\
\text { dicari jawabnya. } \\
\text { Menjadi pembelajar sepanjang hayat, ingin tahu. }\end{array}$ \\
\hline
\end{tabular}

\section{Hubungan 5M dengan Problem-based Learning (Pembelajaran Berbasis Masalah)}

Problem-Based Learning (PBL) atau Pembelajaran Berbasis Masalah adalah pembelajaran yang menggunakan masalah nyata dalam kehidupan sehari-hari (otentik) yang bersifat terbuka (open-ended) untuk diselesaikan oleh peserta didik untuk mengembangkan keterampilan berpikir, keterampilan menyelesaikan masalah, keterampilan sosial, keterampilan untuk belajar mandiri, dan membangun atau memperoleh pengetahuan baru. Pembelajaran ini berbeda dengan pembelajaran konvensional yang jarang menggunakan masalah nyata atau menggunakan masalah nyata hanya di tahap akhir pembelajaran sebagai penerapan dari pengetahuan yang telah 
dipelajari. Pemilihan masalah nyata tersebut dilakukan atas pertimbangan kesesuaiannya dengan pencapaian kompetensi dasar.

Pembelajaran Berbasis Masalah (PBL) berbeda dengan metode problem solving (penyelesaian masalah). PBL menyajikan pembahasan permasalahan sebelum mempelajari konsep yang dibutuhkan untuk penyelesaiannya, sehingga permasalahan menjadi basis dalam belajar. Sementara itu, metode problem solving pada umumnya menyajikan pembahasan konsep terlebih dahulu, lalu diikuti dengan pembahasan permasalahan. Secara sederhana, perbedaan PBL dengan problem solving adalah sebagai berikut: (1) PBL-proses memperoleh pengetahuan berdasarkan identifikasi tentang apa yang perlu dipelajari dan (2) Problem solving-proses pengambilan keputusan berdasarkan pengetahuan awal dan menalar. Jadi, PBL lebih luas daripada problem solving (Sani, 2015).

Strategi belajar berbasis masalah merupakan strategi pembelajaran dengan menghadapkan siswa pada permasalahan-permasalahan praktis sebagai pijakan dalam belajar atau dengan kata lain siswa belajar permasalahan-permasalahan (Wena, 2010). Dalam pembelajaran berdasarkan masalah guru membantu siswa mendefeniskan dan mengorganisasikan tugas belajar yang berhubungan dengan masalah (menetapkan topik, tugas, jadwal, dan lain-lain) (Aqib, 2014). Sintaks Pembelajaran Berbasis Masalah sebagai berikut: (1) identifkasi masalah, (2) mendefenisikan masalah, (3) mencari solusi, (4) melaksanakan strategi, dan (5) mengakaji kembali dan mengevaluasi pengaruhnya (Wena, 2010). Selanjutnya sintaks tersebut dihubungkan dengan unsur dalam pendekatan saintifik. Hubungan 5M dengan Pembelajaran Berbasis Masalah tampak pada Tabel 2 berikut.

Tabel 2. Hubungan 5M dengan Sintaks Pembelajaran Berbasis Masalah

\begin{tabular}{|c|c|c|}
\hline Kegiatan Pokok 5M & Sintaks & Deskripsi \\
\hline Mengamati & terhadap & $\begin{array}{l}\text { Guru menyajikan masalah nyata kepada } \\
\text { pesertadidik. } \\
\text { Cinta kebenaran. }\end{array}$ \\
\hline Menanya & $\begin{array}{lr}\text { Organisasi } \quad \text { belajar, } \\
\text { menganalisis atau } \\
\text { mendefenisikan masalah }\end{array}$ & $\begin{array}{l}\text { Guru memfasilitasi peserta didik untuk } \\
\text { memahami masalah nyata yang telah disajikan, } \\
\text { yaitu mengidentifikasi apa yang mereka ketahui, } \\
\text { apa yang perlu mereka ketahui, dan apa yang perlu } \\
\text { dilakukan untuk menyelesaikan masalah. } \\
\text { Peserta didik berbagi peran/tugas untuk } \\
\text { menyelesaikan masalah tersebut. }\end{array}$ \\
\hline $\begin{array}{l}\text { Mengumpulkan } \\
\text { Informasi }\end{array}$ & $\begin{array}{l}\text { Membimbing } \\
\text { penyelidikan } \\
\text { individu/kelompok }\end{array}$ & $\begin{array}{l}\text { Guru membimbing peserta didik melakukan } \\
\text { pengumpulan data/informasi (pengetahuan, } \\
\text { konsep, teori) melalui berbagai macam cara untuk } \\
\text { menemukan berbagai alternatif penyelesaian } \\
\text { masalah. Kerja keras, kreatif }\end{array}$ \\
\hline Mengasosiasi & $\begin{array}{l}\text { Pengembangan dan } \\
\text { penyajian hasil } \\
\text { penyelesaian masalah }\end{array}$ & $\begin{array}{l}\text { Guru membimbing peserta didik untuk } \\
\text { menentukan penyelesaian masalah yang paling } \\
\text { tepat dari berbagai alternative pemecahan masalah } \\
\text { yang peserta didik temukan. }\end{array}$ \\
\hline
\end{tabular}

BIOLOGI SEL (YOL 8 NO 1 EDISI JAN-JUN 2019 ISSN 2252-858X/E-ISSN 2541-1225) PAGE 97 


\begin{tabular}{|l|l|l|}
\hline & & $\begin{array}{l}\text { Peserta didik menyusun laporan hasil penyelesaian } \\
\text { masalah, misalnya dalam bentuk gagasan, model, } \\
\text { bagan, atau Power Point slides. } \\
\text { Kerjasama, kreatif }\end{array}$ \\
\hline Mengkomunikasikan & $\begin{array}{l}\text { Analisis dan evaluasi } \\
\text { proses penyelesaian } \\
\text { masalah }\end{array}$ & $\begin{array}{l}\text { Guru memfasilitasi peserta didik untuk melakukan } \\
\text { refleksi atau evaluasi terhadap proses penyelesaian } \\
\text { masalah yang dilakukan. } \\
\text { Keberanian, cinta kebenaran. }\end{array}$ \\
\hline
\end{tabular}

\section{Hubungan 5M dengan Project-based Learning (Pembelajaran Berbasis Proyek)}

Project-based Learning (PjBL) atau Pembelajaran Berbasis Proyek adalah kegiatan pembelajaran yang menggunakan projek atau kegiatan sebagai proses pembelajaran untuk mencapai kompetensi sikap, pengetahuan dan ketrampilan. Penekanan pembelajaran terletak pada aktivitas-aktivias peserta didik untuk menghasilkan produk dengan menerapkan keterampilan meneliti, menganalisis, membuat, sampai dengan mempresentasikan produk pembelajaran berdasarkan pengalaman nyata. Produk yang dimaksud adalah hasil projek dalam bentuk desain, skema, karya tulis, karya seni, karya teknologi/prakarya, dan lain-lain. Pembelajaran ini memperkenankan pesera didik untuk bekerja secara mandiri maupun berkelompok dalam menghasilkan produk nyata.

Kerja proyek memuat tugas-tugas yang kompleks berdasarkan kepada pertanyaan dan permasalahan (problem) yang sangat menantang, dan menuntut siswa untuk merancang, memecahkan masalah, membuat keputusan, melakukan investigasi, serta memberikan kesempatan kepada siswa untuk bekerja secara mandiri (Thomas, dkk, 1999 seperti dikutip oleh Wena, 2010). Terdapat hubungan antara startegi pembelajaran berbasis proyek dengan peningkatan kreativitas (pola pikir dan karya) dan hasil belajar (kognitif, afektif, dan psikomotorik) peserta didik (Banawi, 2014). Pembelajaran berbasis proyek dapat membantu siswa meningkatkan keterampilan dan memecahkan masalah secara kolaboratif (Wena, 2010).

Problem Based Learning dan Project Based Learning secara umum hampir sama, sehingga banyak para pendidik yang mengalami kebingungan dalam membedakannya. Oleh karena itu, guru maupun calon guru perlu mengetahui persamaan dan perbedaan dari kedua pembelajaran tersebut. Persamaan antara PBL dan PjBL antara lain: (1) Kedua model pembelajaran menekankan pada partisipasi aktif peserta didik (student centered learning), (2) Keduanya menggunakan pendekatan konstruktivisme, (3) Permasalahan dalam kehidupan sehari-hari digunakan oleh kedua metode ini sebagai upaya untuk meningkatkan prestasi belajar siswa, dan (4) Kedua model sama-sama menggunakan metode pemecahan masalah (problem solving). Perbedaan antara PBL dan PjBL diantaranya PBL menghasilkan rencana atau strategi, sedangkan PjBL melakukan tindakan dalam melaksanakan rencana tersebut (Mayasari dkk., 2016). 
Sintaks Pembelajaran Berbasis Proyek sebagai berikut: (1) penyajian permasalahan, (2) membuat perencanaan, (3) menyusun penjadwalan, (4) memonitor pembuatan proyek, (5) melakukan penilaian, dan (6) evaluasi (Sani, 2015). Selanjutnya sintaks tersebut dihubungkan dengan unsur dalam pendekatan saintifik. Hubungan 5M dengan Pembelajaran Berbasis Proyek tampak pada Tabel 3 berikut.

Tabel 3. Hubungan 5M dengan Sintaks Pembelajaran Berbasis Proyek

\begin{tabular}{|l|l|l|}
\hline Kegiatan Pokok 5M & \multicolumn{1}{|c|}{ Sintaks } & \multicolumn{1}{|c|}{ Deskripsi } \\
\hline Mengamati & Penentuan proyek dengan peserta didik \\
\hline Menanya & $\begin{array}{l}\text { Menyusun perencanaan dan } \\
\text { langkah-langkah penyelesaian } \\
\text { projek bisa melalui percobaan. } \\
\text { menentukan tema/topic projek }\end{array}$ & $\begin{array}{l}\text { Guru memfasilitasi peserta didik untuk } \\
\text { merancang langkah-langkah kegiatan } \\
\text { penyelesaian beserta } \\
\text { pengelolaannya projek } \\
\text { Kreatif. }\end{array}$ \\
\hline $\begin{array}{l}\text { Mengumpulkan } \\
\text { Informasi }\end{array}$ & $\begin{array}{l}\text { Penyusunan jadwal pelaksanaan } \\
\text { projek }\end{array}$ & $\begin{array}{l}\text { Guru memberikan pendampingan kepada } \\
\text { peserta didik melakukan penjadwalan } \\
\text { semua kegiatan yang telah dirancangnya. } \\
\text { Kerjasama, kejujuran, kerja keras. }\end{array}$ \\
\hline Mengasosiasi & $\begin{array}{l}\text { Penyelesaian laporan proyek } \\
\text { dengan fasilitasi dan monitoring } \\
\text { guru. }\end{array}$ & $\begin{array}{l}\text { Guru memfasilitasi dan memonitor peserta } \\
\text { didik dalam melaksanakan rancangan } \\
\text { projek yang telah dibuat. } \\
\text { Kerja keras. }\end{array}$ \\
\hline Mengkomunikasikan & $\begin{array}{l}\text { Penyusunan laporan dan } \\
\text { presentasi/publikasi hasil projek. } \\
\text { Evaluasi proses dan hasil projek. }\end{array}$ & $\begin{array}{l}\text { Guru memfasilitasi peserta didik untuk } \\
\text { mempresentasikan dan keberanian } \\
\text { mempublikasikan hasil karya. } \\
\text { Guru dan peserta didik pada akhir proses } \\
\text { pembelajaran melakukan refleksi terhadap } \\
\text { aktivitas dan hasil tugas projek menjadi } \\
\text { pembelajar sepanjang hayat. }\end{array}$ \\
\hline
\end{tabular}

\section{KESIMPULAN}

Dari pemaparan mengenai pendekatan saintifik dan model pembelajaran dapat disimpulkan bahwa pendekatan saintifik merupakan pendekatan berbasis ilmiah, meliputi kegiatan 5M yaitu mengamati, menanya, mengumpulkan informasi, mengasosiasi atau menalar dan mengkomunikasikan. Pendekatan saintifik dapat digunakan secara bersamasama dengan model pembelajaran. Lima tahapan pendekatan saintifik dapat disenergikan dengan sintaks model pembelajaran yang ada. Hasil kajian ini merupakan bekal pengetahuan bagi guru dalam menyusun rencana pembelajaran dan menerapkannya dalam pembelajaran di kelas.

\section{DAFTAR PUSTAKA}

Aqib, Zainal. (2014). Model-model, Media dan Strategi Pembelajaran Kontekstual (Invatif). Bandung: CV Yrama Widya.

Banawi, Anasufi. (2014). Keefektifan Strategi Project Base Learning dalam Meningkatkan Kreativitas dan Hasil belajar IPA-Fisika pada Mahasiswa 
Fakultas Ilmu Tarbiyah dan Keguruan IAIN Ambon Angkatan 2013. Jurnal Inovasi, 8(4), hlm. 369-380.

Herdian. (2010). Metode Pembelajaran Discovery (Penemuan). Diakses dari http://www.salamedukasi.com/2014/06/definisi-contoh-model-

pembelajaran.html. http://tryplek.blogspot.com/2011/06/pengertianpendekatan-struktural $/ \mathrm{html}$ ? $\mathrm{m}=1$.

Kementerian Pedidikan dan Kebudayaan. (2016). Panduan Teknik Pembelajaran Dan Penilaian Di Sekolah Dasar. Jakarta: Direktorat Jendral Pendidikan Dasar Dan Menengah. Direktorat Jendral Pembinaan Sekolah Dasar

Kementerian Pendidikan dan Kebudayaan. (2018). Materi Penyegaran Istruktur Kurikulum 2013 Sekolah Menengah Pertama. Jakarta: Direktorat Jendral Pendidikan Dasar Dan Menengah

Mayasari, Tantri., Kadarohman, Asep., Rusdiana, Dadi, dan Kaniawati, Ida. (2016). Apakah Model Pembelajaran Problem Based Learning dan Project Based Learning mampu Melatihkan Keterampilan Abad 21? JPFK, 2(1), hlm. 48-55.

Peraturan Menteri Pendidikan dan Kebudayaan Nomor 22 Tahun 2016 tentang Standar Proses Pendidikan Dasar dan Menengah.

Permendikbud Nomor 103 Tahun 2014 tentang lampiran pembelajaran pada pendidikan dasar dan pendidikan menengah.

Roestiyah, N.K. (2008). Strategi Belajar Mengajar. Jakarta: Rineka Cipta.

Sani, Ridwan Abdullah. (2015). Pembelajaran Saintifik untuk Implementasi Kurikulum 2013. Jakarta: Bumi Aksara.

Undang-Undang Nomor 20 Tahun 2003 tentang Sistem Pendidikan Nasional.

Wena, Made. (2010). Strategi Pembelajaran Inovatif Kontemporer (Suatu Tinjauan Konseptual Operasional). Jakarta: Bumi Aksara. 